\title{
Selected problems of protecting and managing historical ruins in Poland
}

\author{
Anna Fortuna-Marek, Bogusław Szmygin \\ Department of Conservation of Built Heritage, Faculty of Civil Engineering and Architecture, \\ Lublin University of Technology,e-mail: afortuna@poczta.onet.pl,b.szmygin@pollub.pl
}

\begin{abstract}
Historical ruins have long been the object of interest for the research workers of various disciplines as well as the conservators of historical monuments. The main problem is the form of protection. The standard of protecting ruins in the so-called permanent ruin form was elaborated two centuries ago, however, it is still the subject of numerous discussions, conferences, scientific-research works. ${ }^{1}$ The main source of doubts as to the permanent ruin is its incompleteness, (deficiency) illegibility and the highly restricted possibilities of making any use of it, whereas the contemporary protection of monuments assumes their accessibility and the widest possible use for contemporary functions. That is why the main issue in contemporary maintenance of historical ruins is to ensure them a proper management system. The problem of protecting historical ruins has universal character. In Poland it concerns the resources of about 200 historical ruins, first and foremost of the mediaeval castles. That is why the Polish conservator circles have intensified the works aiming at the solution of the problem through the organization of programs, projects and conferences ${ }^{2}$. A highly estimated result of those efforts is a programmatic document entitled "The Protection Charter of Historical Ruins"3. It comprises a set of rules that determine the form of maintenance of historical ruins. However, the issues of management, development and use of the historical ruins still await a solution.
\end{abstract}

Keywords: historical ruins, management and development of the ruins.

\section{Introduction}

The contemporary theory and practice of managing historical ruins - apart from the purely conservatory issues - concentrates upon the opportunities and methods of taking advantage of them, their use and development. The basic objective of those activities will be the use of those ruins for tourism. Practically, however, it implies various types of interference in the monumental form and substance of the historical ruins. It often even leads to partial reconstruction of the ruins or erection of additional parts of modern volu-

1 First of all, we should point out as the latest Works, the post-conference publications PKN ICOMOS devoted to the issue of historical ruins (Janowiec 2005, Lublin 2006, Działdowo 2007, Gubin 2008, Ciechanowiec 2009, Kożuchów 2010). Information concerning publications are accessible at the Internet site: http://www.icomos-poland.org.pl/publikacje.html.

2 Carried out and organised mainly by PKN ICOMOS originally in cooperation with the participation of the Lublin University of Technology and Warsaw University of Technology.

3 "The Protection Charter of Historical Ruins" (the rule of historical ruins protection) was accepted by the Resolution of the General Assembly of the Members of the Polish National Committee. ICOMOS on December $4^{\text {th }} 2012$. The contents of the Charter is accessible on the Internet site: http://www.icomospoland.org/pl/dokumenty/uchwaly/130-karta-ochrony-historycznych-ruin.html. 
metric objects. It results from the need to employ new utility functions, most frequently aimed at enriching the tourist offer and/or at commercial use.

A separate issue is the tendency to carry out full reconstruction; several (not really numerous )cases occurred in Poland in recent years, with the effect of transforming the historical ruin into a full volumetric form and losing the specific object of protection, i.e. the permanent ruin. It leads us to the statement that the contemporary ways of managing historical ruins oscillate between extremities - from the continuation of attitudes and rules developed as early as in $19^{\text {th }}$ century by J. Ruskin or W. Morris to the arguments stating that reconstruction (although it is, in fact, reduced to more or less clever accomplishments of conservatory creations) is fully justified - not only for utilitarian reasons, but also, sometimes, for ideological reasons (reconstruction of mediaeval castles in order to strengthen the sense of relevant values and of national identity. With such extreme views and the methods of managing historical ruins (most often accomplished on the basis of the conservator's agreement) the discussion concerning their protection and management is relevant indeed and reasonable. Moreover, conservation and maintenance, using and development as well as managing historical ruins pose a lot of problems because of the specific character of this category of monuments - both for the conservator and other kinds of problems which are not concerned with conservation and do not occur with such intensity in case of other immovable monuments.

Talking about and protection and management of the cultural heritage, also with reference to the specific part of this heritage ,i.e. the ruins of mediaeval castles we should concentrate upon several issues - characteristic of the specific resource and its value, characteristic of the protection system, as well as characteristic of development and use ${ }^{4}$.

\section{A resource and its values}

Historical ruins of mediaeval castles in Poland are barely a small percentage of the resources of protected historical monuments. As far as we consider only the objects registered as immovable historical monuments, there are hardly a hundred and several dozen objects counted against the overall number of 70000 objects registered as immovable monuments. There are no precise figures concerning this resource. According to the analyses carried out in 2012 the number of ruins of mediaeval castles registered as monuments was $136^{5}$. The number was then verified on the basis of a documentation analysis and a partial area verification and determined as 124 objects $^{6}$. On the other hand, according to the data accessible on the official internet site of the National Heritage Institute there are less than $100^{7}$ mediaeval castles registered as immovable monuments. According to other data (taking into account not only the objects registered as monuments) their number is about $200^{8}$. The reason for the lack of precise identification of mediaeval castle ruins are among others: the problems related to determining the time spans as well as the approximate estimation of dating back of numerous objects, not very precise and manifold determination of this type of monuments in the decisions concerning their registration (e.g. a certain number of

4 The issues concerning exploitation and development have been analysed in a separate report.

5 I. Malawska, Granice ruin zamkowych i granice ich otoczenia, /in:/ Zamki w ruinie - zasady postępowania konserwatorskiego, ed. B. Szmygin, P. Molski, Warsaw - Lublin 2012, pp. 75-81.

${ }^{6}$ One of the tasks accomplished within the confines of a research Project carried out by a team of employees of Lublin University of Technology and Warsaw University of Technology.

7 The Internet site: www.zabytek.pl.

8 The list elaborated by G. Grajewski within the confines of accomplishment of the INTERRED project concerning historical ruins of castles. 
historical castle ruins is determined in the decisions as a castle, a fortified manor-house, relics or remnants of a castle), the lack of systemic monitoring (and information) concerning the state of the ruins (the state of some part of the resource is very bad, whereas some ruins of the castles have been reconstructed and have lost the character of ruins) $)^{9}$. Talking about the resources (and their number) of the castle ruins it should be noticed that the former specifications did not comprise the objects which were not registered as immovable monuments, however, they were mentioned in the, so-called communal record of monuments, i.e. the list of monumental objects whose carrying out falls within the competence of town or commune municipality. Undoubtedly most castle ruins mentioned in the communal records should qualify for being protected by including them in the register of monuments.

Among the legally protected castle ruins we may single out, for the sake of research, four groups, which are, generally the consequence of the decisions and methods of the conservator's activities and the accomplishment of the activities by the owners (or the lack of owners):

- Historical ruins of castles, unsecured in the form of a permanent ruin, deteriorating and endangered with complete destruction, or secured only temporarily.

- Historical ruins of castles, maintained, conservated and secured in the form of a permanent ruin, without the introduction of contemporary volumetric spacial forms (or to a minimal extent only).

- Historical ruins of castles, maintained, conservated and partly secured in the form of a permanent ruin, partly reconstructed in order to introduce the contemporary forms of use. Sometimes determined as a transitory form between a ruin and a cubature $^{10}$.

- The objects registered as a historical ruin, that were reconstructed to such an extent, that they lost the features of a historical ruin. It should be accepted that this group of objects (even if their present architectural structure contains the preserved monumental substance) is no longer the object of interest as the form of permanent ruin.

Such a division of historical ruins of castles introduced for the sake of the research allows to reveal the fact that the number of classical permanent ruins can be drastically, irreversibly reduced. We should be reminded that the resources of this category of monuments is rather scarce presently. In such a situation (with the assumption that the main objective of protecting and managing the specific resource of monumental objects is keeping the objects within the second group), starting discussions, activities and projects aimed at protection and management understood in this way should become an important element of conservation policy and practice.

The suggested division also implies a certain range of protective and managerial activities as the actual technical state, the function performed by the monuments (or the lack of function), the existent form (permanent ruin or permanent ruin with partial reconstruction) have a crucial meaning while taking decisions by a conservator as far as the range and

\footnotetext{
9 More about the issues with the qualification of the amount of historical ruins of mediaeval castles B. Szmygin, Historyczne ruiny średniowiecznych zamków w Polsce - ocean stanu zasobu i prac konserwatorskich, /in:/ Zamki w ruinie - zasady postepowania konserwatorskiego, ed. B. Szmygin and P. Molski, Warsaw - Lublin 2012, p. 28.

${ }^{10}$ B. Szmygin, Problem ruin zamku w świetle wspótczesnej teorii i praktyki konserwatorskiej, /in:/ Trwała Ruina. Problemy utrzymania i adaptacji, ed. B. Szmygin, Lublin 2006, p. 33. The author Hus describes the ruins of the castle of Janowiec, noticing that "one may also state that in the present form Janowiec is neither a ruin nor a cubature".
} 
type of activities at the monument site are concerned as well as the opportunities of using the ruin and taking advantage of it for contemporary purposes.

An important problem concerning the historical ruins of castles in Poland is that we lack any estimation of the resource with reference to its value. Of course, we might say that the scarcity of those monuments compared to the overall number of the resources, their age, associations with important historical events and personages as well as the usually significant landscape values make them an immensely precious element of the Polish cultural heritage. However, for a number of reasons, it is not a set of equal value. In our hitherto conservation theory and practice in Poland no method of estimation of monumental castle ruins has been developed which would allow the possibly most objective comparative estimation method based on criteria. There is a need for overall estimation of this group of monuments - valorizing and setting a hierarchy of particular objects against the others. There is also a need for pointing out (within the confines of a given object) those features and elements (attributes) that make the value of a specific object. That does not mean, of course, that there are no scientific descriptions or documentation of the particular (selected) monuments that would present the value of those objects. The basic document that, apart from the subject and pointing out the limits of protection, should include the estimation of the value of an object is the decision about registration as a monument. Most of the mediaeval castle ruins as the extremely precious objects were included in the group for legal protection through registration in between 50's and 70's of 20'th century. In the motivation of most of those decisions which gave the ruins the status of a monument, there is either no information concerning the values that a given object represents or it is reduced to an enigmatic statement that the object presents historical, artistic or scientific values. The degree of recognition and value estimation of the particular objects is varied. Some of the ruins have a rich scientific-research documentation - archeological, architectural research, historical studies, however, the fact that they are dispersed across various documents prepared at various times as well as the lack of elaborations summing up those researches makes the estimation of their value difficult. Moreover, the documents do not contain any analysis of authenticity and integrity of those objects ${ }^{11}$. Such a situation also hinders taking the proper decisions and taking up conservation activities. Dispersion, incompleteness and using no standard records of evaluation based upon the scientific workshop really hinders the comparative valorization of the monumental resources of the ruins - the estimation of their representativeness and uniqueness as the basis for developing the protection strategy and designating the objects to be registered as monuments of history ${ }^{12}$. Such an overall, systemic valorization would also be the basis to choose the part of the resource towards which, with respect to the represented values, all the activities focused on a given object were submitted to the preservation of those values.

\section{The forms of protection}

The forms of monument protection in the Polish legal system is defined by the Law of monument protection and monument preservation. These are:

\footnotetext{
${ }^{11}$ Such conclusions result, among others, from the research project accomplished by the team of LUT and WUT employees entitled Zamki w ruinie - zasady postępowania konserwatorskiego, cf. P. Molski Pozakonserwatorskie uwarunkowania ochrony zamków $w$ ruinie, /in:/ Zamki $w$ ruinie - zasady postępowania konserwatorskiego, ed. B. Szmygin and P. Molski, Warsaw - Lublin 2012, p. 51.

${ }^{12}$ Ibidem, p. 51.
} 
- Registration as a monument on the basis of a decision issued by the voivodship monument conservator in his official capacity or at an application of the owner of the immovable monument. The premises of the registered monument may also be registered. The monument register is divided into: register A comprising immovable monuments, register $\mathrm{B}-$ movable monuments and register $\mathrm{C}-$ archeological monuments.

- Regarding as a registered immovable monument of history or a registered part of a culture park of a specific cultural value by the President of the Polish Republic.

- Establishing a culture park in order to protect the cultural landscape and preserving the outstanding landscape areas with immovable monuments.

- The statement concerning protection in the local area development plan or in the decision of establishing the location of public goal investment, or the land development decision the latest two forms of protection fall within the competence of the local municipality (town or community).

In the legal system of monument protection in Poland - with reference to the immovable objects such as the historical castle ruins - the basic form of their protection is their registration as immovable monuments. Such a registration causes a series of consequences both for the owner of the monumental object and for the organs of government (and municipal) administration, whose duties comprise protection, preservation and handing down to posterity the monumental resource protected by law. The preserved historical ruins of mediaeval castles are for their most part formally regarded as legally protected monumental objects as a result of their registration as immovable monuments (register A). It should also be stated that some part of the monumental resource of historical ruins - most often it is applied to the archeological localities whose form has been discovered during the archeological research or whose part-visible on the surface of the ground was preserved as a relic and is protected as a resource of archeological monuments, registered as an archeological monument (Register C). Hence, there is a certain lack of consequence - the objects of comparable form and state of preservation are registered under $\mathrm{A}$ or $\mathrm{C}$.

Registration as a monument in the Polish legal system is concerned as the basic tool of developing the conservation policy and an efficient protection tool which implies some executable laws and duties. The problem which recurs in the in the dispute concerning the quality of monument protection in Poland (not only with respect to castles) is, among others, the essential content and the correct form of the decision concerning registration. The essential content should be understood here as various aspects of the decision concerning the registration: the precise designation of the object of registration and the protection range, the proper justification of the decision containing the detailed description of the protected values, using explicit, legally defined concepts and, last but not least, the representativeness of the whole set from the point of view of the cultural heritage of the coun$t r y^{13}$. The monument register which has been created for several dozens of years in the changing legal and political conditions and based upon varied criteria presently does not have a uniform character. Decisions concerning registration are often seriously faulty, most often the object is not well designated and the protection range not properly defined. In many cases it is not possible to define precisely the limits of the protected monument. The

\footnotetext{
${ }^{13} \mathrm{~J}$. Brudnicki, Problem wyjaśniania $i$ prostowania treści decyzji o wpisie do rejestru zabytków w kontekście wad i uchybień tkwiacych w tym rejestrze, „Kurier Konserwatorski” no 10, 2011, p. 40.
} 
faults and transgressions also occur in the decisions of the people who register castle ruins ${ }^{14}$.

Another protection form (defined as the Monument of History) in the case of ruins of mediaeval castles does not, in fact occur as a separate object of protection. No castle ruins in Poland have been individually regarded as a Monument of History. It is only in two cases that the castle ruins are within the confines of monumental town complexes regarded as Monuments of History. It applies to the castle ruins in Kazimierz Dolny (The Monument of History called "Kazimierz Dolny", comprising the monumental complex of the city) and the ruins of a castle of the Teutonic Knights in Torun (The Monument of History called "Torun - The Old Town and the New Town").

Analyzing yet another legal protection form, namely the culture park one can state that the form, functioning in the Polish system of monument protection since 2003 and falling within the competence of local municipalities has not gained any real understanding or acceptance. The right to organize culture parks has not been taken up by the local municipalities, although it seems that in case of the specific character of castle ruins that form dominants of the landscape and have great exposition values, a culture park would have been a perfect instrument to reinforce the area protection, so important in case of castle ruins. Probably the only culture park whose protection object is the complex: archaeological relics of the castle, the stronghold chapel, the walls and the fortifications (along with the wider cultural-landscape context) is the Castle Hill Culture Park in Sieradz, created by the resolution of the Town Council in Sieradz in 2009.

The commune monument record (henceforward called cmr) mentioned in the presentation of the castle ruin resources is not a legally determined form of protection. According to the Law of Monument Protection carrying out the cmr falls within the competence of town and commune local governments. The cmr takes into account all the immovable (and archeological) monuments and other immovable monuments pointed out by the president, mayor or a Chief Officer of a group of villages. However, the objects qualified for the cmr are not submitted to a form of monument protection although they should be comprised by such protection - among others by taking them into account in the local development plan.

A separate issue concerning the protection of castle ruin resources - a crucial one in view of their specific locality and values which express the characteristic elements and features of the landscape and culture - is the protection of their environment, exposition and, in a broader sense, the cultural landscape. The area protection may be accomplished through various forms of legal protection. Firstly, the area around the castle ruins may be registered as a monument as an area presenting monumental values or as the monument premises ${ }^{15}$. Secondly, the range and method of protection of the premises, the monument exposition and/or the cultural landscape may be formulated in the local area development plan and also concerned with the development of culture parks - i.e. through the forms of protection falling within the competence of the town and commune local governments.

\footnotetext{
14 The problem was analyzed by I. Malawska with respect to the castle ruin: Granice ruin zamkowych i granice ich otoczenia. Czy na podstawie decyzji o wpisie do rejestru zabytków nieruchomych można określić granice przedmiotu, który chronimy?, /in:/ Zamki w ruinie - zasady postępowania konserwatorskiego, ed. B. Szmygin and P. Molski, Wasaw - Lublin 2012, pp. 75-81.

${ }^{15}$ The Law of Monument Protection defines the premises in the following way: Premises - the area around or next to the monument pointed out in the decision of registration of the area as a monument in order to protect the landscape values of the monument and its protection from the harmful effect of the atmospheric factors.
} 


\section{Protection and preservation of monuments}

The Law of Monument Protection and Preservation defines the concept of protecting monuments and their preservation. The protection of monuments is carried out by the units of public administration and it consists in taking up the activities aimed at: securing the legal, organizational and financial conditions allowing to preserve the permanent state of the monuments as well as their development and maintenance; preventing the dangers threatening the monument value; preventing damage and improper use of the monuments; controlling the state of preservation and the appropriate assignment of the monuments; taking into account the protective tasks in the site development planning and shaping the environment.

At the same time the owner of the monuments is also responsible for their maintenance. The basic tasks and duties resulting from the fact of "managing " the monument are determined as monument protection, which consists, particularly, in creating the conditions: the scientific research and documentation of the monument; carrying out preservation, restoration and construction works at the monument site; securing and maintaining the monument in the best possible state; using the monument in the way ensuring the permanent preservation of its value; promoting and spreading knowledge concerning the monument as well as its significance for history and culture.

Considering protection and preservation of the historical castle ruins we should also pay attention to the important role of the local government units concerning this range of issues. The role of the local government has two basic reasons - firstly, the relatively large amount of castle ruins is the property of local government units; secondly, the local governments have at their disposal the specific legal instruments that could affect the improvement of the state and the proper management of the historical castle ruins if they are efficiently used. The activities of the l.g.u. accomplished within the range of monument protection tasks are counted among the specific tasks of the local governments defined in the appropriate laws ${ }^{16}$. The l.g.u. at various levels have to accomplish their tasks of monument protection with respect to monumental objects, whose owners they are. Moreover, the local government is also obliged to carry out the commune monument record, to elaborate the commune program of monument protection and also to take into account the monument protection and preservation in the strategy of community development and the research of the conditions and directions of area development plan. At the same time the communes are entitled to use the instruments of protecting monuments at the local level - by taking protection into account in the local area development plan - as well as to organize and develop culture parks.

\section{Property forms and functions}

The owner's responsibility imposed by the legislator for the proper maintenance and use of the monument is the reason why the owner has the crucial influence upon the protection and management of the historical ruins. The ruins of the mediaeval castles in Poland are presently the properties of various categories of units (local government property, private, state, various associations or foundations property). It is worth noticing that the present ownership conditions both of the objective ruins and all the other categories of

\footnotetext{
${ }^{16}$ First of all: The Law of Monument Protection and Preservation, The Law of planning and area development, The Construction Law, The Law of the local government.
} 
monumental objects in Poland have undergone a radical change after 1989. The change is concerned with a wider issue of the condition changes - they were most often called the conditions of monument protection (before 1989), and then the conditions of heritage management (after 1989). The conditions are concerned, on the one hand with the units taking part in the process of protection and management, on the other hand, the methods of planning and accomplishment of the protection and management. In the system of monument protection in Poland (before 1989) the state property was predominant and it was also the state as well as state conservatory services, that were responsible for preservation and maintenance of the monuments in a good state. Financing of the monument protection was the duty of the state. The method of accomplishment of protection was fully dependent from the state conservatory services. It consisted in giving the objects the status of legally protected monuments, carrying out scientific research of the monuments (also those financed from the state budget and focused upon the object) and the accomplishment of the reconditioning and conservation works (by the state services), as well as providing control. Almost the whole process of the protection activities was carried out by the state. In case of heritage management the conditions are quite different. The heritage (and the monuments) belong to the units of various categories (private property, local governments, state or denomination property) and it is the owner who is financially responsible for maintaining the good state of the monument, possibly taking advantage of some kind of donation (not only those granted by the state but also the local governments of various levels, the EU funds etc.)

Presently castle ruins in Poland most often represent the following forms of property: The local government property, private or state property There is a noticeable coherence between the form of property and perceiving the monument by the owner and, as a consequence - the method and quality of its protection as well as the forms of its use, development and management. On the basis of recognition of those problems in several publications which are the aftermath of the conferences organized by PKN ICOMOS from 2005 to 2013 as well as the observations made by the author of the text one may generalize and attempt the following conclusions:

The ruins within the competence of the local governments (the property of the town and commune local governments are most often used as the properties used for the local development in a broad sense. Their use (and development) is directed at two basic aims the development of culture tourism on the basis of the m0nument which should serve the economical development and shaping the sense of identity of the local community. Those objectives are accomplished through a number of varied activities - mainly promotional and educational. Hence the ruins are often used as the venue of numerous mass events - historical reconstructions, historical picnics, plain-airs for painters, exhibitions, culinary feasts and sometimes also - patriotic celebrations. Such objectives and the ways of their accomplishment are a good reason to make the venues of those events restored and accessible that is why they imply carrying out the restoration and conservation works earlier as well as the suitable functional adaptation of the environment. At the same time - more than once the success of the activities related to the use of ruins, an inflow of tourists, popularity of the place and the organized cultural events releases the tendency to start various investments concerned with providing service subsidiaries and tourist infrastructure within the confines of the ruins, in the neighborhood or on the premises. It sometimes poses a real danger for the value of monumental ruins and their environment.

The privately owned ruins, like in the case of local government property, are used as tourist attraction and the places for cultural activities. Apart from the objectives identical with the ones occurring in case of local government property, i.e. the tourism development 
and, consequently, economic development, the private owners are more commerciallyoriented. The economic calculation, which is rather obvious, is the reason why the activities of the owners are often directed at various kinds of investments in the ruins or on their premises, which would allow to extend the tourist offer - e.g. by restaurant, hotel, resort and recreational services. This kind of activity is not always possible without the introduction of suitable cubature, or other significant interference in the monument or its environment. Obviously, this kind of trend is not unfamiliar for the local government authorities exploiting the historical castle ruins, and at the same time we may point out positive examples of privately owned ruins functioning as tourist attractions, whereas the activities concerning the monument and the way of using it are not dominated by commercial objectives $^{17}$.

Among the exploited and developed mediaeval castle ruins the predominant function is a museum.

\section{Financing}

The system of monument protection financing in Poland is shaped by the legal solutions comprised by several legal acts. The broadest range of the rules of budgeting the protection of a registered monument is regulated by the Law of July 23 $3^{\text {rd }}$, 2003, of monument protection and preservation.

In Polish legal system it is the monument owner who is responsible for maintaining the monument in a good state. Bearing the expense of conservation, restoration and construction works at the monument site is also the duty of a unit with a legal title deed of property (independent of the type of unit; whether it is a private person, a denominational unit, a local government one or a state one). The kind of support in accomplishing this kind of tasks may be public means, given in the form of a purposeful donation granted at the application of the monument owner, a tenant or people authorized by them (physical person, local government unit, or another organizational unit which is the owner or proprietor of the registered monument or is a permanent manager of a monument may apply for a purposeful donation from the state budget for covering the cost of conservation, restoration or construction works at the registered monument site.

The potential sources of finance from the state budget in case of a registered monument is:

- The Ministry of Culture and National Heritage within the range of annually announced programs ${ }^{18}$.

\footnotetext{
${ }^{17}$ An ex ample May be provided by the ruins of „Kamieniec” castle in the Carpatian voivodship, where the private owner (tenant) has been securing and conserving the ruins of a mediaeval castle successively for a dozen or more years, most often using his own financial means without the introduction of additional investments surpassing the solutions which are acceptable for conservatory reasons.

${ }^{18}$ The Minister of Culture and National Heritage has at his disposal the instruments of financing activities concerned with the protection of cultural heritage by virtue of the accepted solutions resulting from the "National Strategy of Culture Development for the years 2004-2020:. Annually the Minister of Culture and National Heritage announces the intake of applications for the programs he is conducting. The programs announced by the decisions of the Minister of Culture and National Heritage are the basis for applications for the programs he is conducting.

The programs announced by decision of the Minister of Cultural Heritage, that can be accomplished, among other by local government units, cultural institutions, universities, churches, denominational organizations, non-governmental organizations and economic operators.
} 
- The Voivodship Monument Conservator ( in each of the 16 voivodships) - the financial means from the state budget from the part at the voivode's disposal assigned for conservation, restoration and construction works at the registered monuments located at the are of a given voivodship.

The law determines the rules of granting donations by the minister and the voivodship monument conservators. Apart from specifying the works at the monument for which the donation may be granted, a certain rule has been accepted, that the donation may cover up to $50 \%$ of the necessary expenditure for the works. Higher budgeting even up to $100 \%$ of the necessary expenditure is possible in the following situations: if the monument has an exceptional historical, artistic or scientific value, or there is a need to carry out complex technological operations, or else, if the state of preservation of the monument requires taking up conservation, restoration or construction works immediately.

Besides the programs of MCandNH and the donations granted by the VMC the socalled help funds from the state budget assigned for the works at monuments may come from the Church Fund, the State Fund of the Disabled People Rehabilitation or the Citizen Initiative Fund.

Moreover the donations for the works at the registered monuments are granted by the constituting offices of the local government units (communes, districts, voivodships) and the rules of the donations are determined in the resolution taken by a given unit.

A significant source of financing the works concerning monuments are the European funds. They come from the following programs:

- The Operational Program Infrastructure and the Environment 2014-2020

- Regional Operational Programs for particular voivodship

- The Rural Areas Development Program

- The Operational Program Fishing and the Sea

- INTERREG

- MCand NH - European funds.

As far as the range of the tax policy in Poland, the following instruments should be mentioned that support the maintenance of monuments:

- Exemption from the property tax of the buildings and areas registered as monuments, on condition that they are preserved in a good state. The exemption from the tax cannot be applied to the parts of the property where any economic activity is carried out.

- Exemption from the land tax of the areas registered as monuments on condition of their preservation and management according to the suitable legal rules.

- Exemption from the forest tax of the forests registered as monuments.

- Exemption from the capital transfer tax concerning movable property on condition that the purchaser protects them and preserves according to the legal rules.

- A $50 \%$ discount of the annual lease payment of the property registered as monument with a possibility of raising or lowering of the discount.

We do not know the exact sum of the financial means from public funds assigned for the restoration and conservation works at the mediaeval castle ruins. Although the data concerning the means granted are revealed, however there are no statistical data that would contain the precise information concerning annual sums of financial help from the state 
budget and the local government budgets assigned for the restoration and conservation works divided into various "kinds" of monuments ${ }^{19}$.

\section{Estimation of dangers and monitoring}

In Polish system of monument protection the problem of dangers threatening the monuments - their identification, prevention and elimination may be solved mainly by the accomplishment of the statements of The Law of Monument Protection and Preservation, which was intended by the legislator to provide suitable tools in order to prevent the unfavorable activities threatening legally protected monumental objects. The issues of preventing various threats that endanger the protected objects and monumental areas are legally defined, among others by determining the forbidden activities and specification of the activities that require permission of the voivodship monument conservator. The protection of monuments carried out by the public administration unit consists, among others in preventing threats that could affect the value of a monument in a negative way, and in counteracting the damage and the and the improper exploitation of the monument. Besides, the conservatory services are endowed with the prerogatives to control the monument and its threats. The threats should also be identified by the monument owner who is obliged to inform the conservatory services immediately about any danger. Practically, however, (and for many reasons) those activities are not often accomplished or executed. There is also a need for systemic activities within this realm, both with regard to the identification and counteracting threats (monitoring threats) as well as carrying the monitoring of the management activities.

The form of an overall, systemic enterprise carried out on the basis of unified methodological assumptions (for the whole resource of registered immovable property monuments) and concerning, among others, the threats, was a verification of the monumental resources carried out by the National Heritage Institute during the years $2009-2015^{20}$. All the monuments were submitted to an area view and the basic objective of the verification was to establish the actual resource of the legally protected immovable property monuments. That is why the verification was focused upon pointing out several verification groups: the no-longer existing objects, objects taken to museums and skansen museums and the objects that have lost their monumental values - in order to cancel them from the monument register. The verification also helped to point out the monuments directly endangered with the loss of their monumental value, in order to make the conservatory services take up the immediate restoration activities. The verification and estimation of the state of the monuments carried out in 2016 at the representatively pointed out statistical specimen has become the basis for the elaboration of the Complex report concerning the state of preservation of the registered immovable property monuments (Register Books

\footnotetext{
${ }^{19}$ A certain impression of the scale of these means can be supplied by an ex ample of one of major Project at the castle ruins carried out during the recent years. A really big investment at the castle of Krzyżtopór in Ujazd completed in 2014, comprising among other: full-protection of the monument structure, providing new roves in several parts with a professional guttering, adapting one of the bastions to be a new, functional part of the castle to be a new, functional part of the castle (among others with office rooms, a conference room, toilets), recreation of the gardens, providing illumination that would allow sightseeing at night, development of the parking spaces, demarcation of tourist paths cost almost PLN 12m; revitalization of the castle in Chęciny during the years 2013-2015 - more than PLN 8m; the castle in Ciechanów - more than PLN $11 \mathrm{~m}$.

20 The verification comprised the monuments registered before September 2008, i.e. 62291 objects.
} 
$A$ and $C)^{21}$. However, the report cannot be the basis for presenting the overall estimation of the state of preservation and threats of the mediaeval castle ruins submitted to protection by the act of registering them. It results mainly from to facts - the lack of a precise determination of the object of protection (and the onomatology) with respect to the castle ruins in the decisions concerning registration, as well as the fact, that the statistically pointed out specimen of monuments submitted to a detailed estimation of the state of preservation (in the technical sense as well as the monumental substance) was not representative for the particular categories of monuments (also the castle ruins). However, some data from the report are worth quoting that point out the scale of disadvantageous phenomena and threats with respect to the registered castles ${ }^{22}$. The verification group determined as: specially endangered objects that did not lose their monumental values ${ }^{23}$ comprised $15 \%$ of the overall number of 405 registered castles. The proportion of castles endangered with the loss of their value is $30 \%$ of the endangered objects coming from the mediaeval period ${ }^{24}$, while 15 castles regarded as endangered objects are privately owned.

In case of historical ruins of castles the identification of threats and monitoring those objects is a specially significant issue. The specific character of these monuments (first of all the exposition of the walls to the operation of atmospheric factors), the climatic conditions typical for Poland and a relatively non-durable material of a great number of the ruins ( sandstone, limestone, bricks) are the reasons of the rapidly progressing negative changes of their technical state. With respect to the unexploited and unsecured ruins the process is really fast. The fact that no periodical, repeated estimations of the state of the monument resource is the reason why our knowledge of the resource and its state is incomplete. Another crucial problem and a threat for the value of the resource is the development of the ruins for their new functions which is usually concerned with the intentions (and accomplishments of the manager to reconstruct some parts of the object.

\section{Conclusions and Postulates ${ }^{25}$}

1. The resource of mediaeval castles historical ruins that has been preserved in Poland is rather scarce as compared with almost all legally protected monumental objects.

21 The items of information have been quoted on basis of not-yet-published working materials from the Complex report of the preservations state of the immovable property registered monuments (Register Books A, and C) - in the collection f NID. The report will be published on December 2017. The completion of the report required the statistical research of the state of preservation of immovable registered monuments, specimen representative for the resource of monument register comprising 1303 immovable objects located across the area of the whole country.

${ }^{22}$ Most of the historical castle ruins were taken into account within the group of castles.

${ }^{23}$ In the assumptions for verification the following threats were mentioned: the lack of an owner, lack of protection, improper exploitation, non-regulated legal state, landslips, ground-water, mining - damages, investment threats of the object, investment threats of the premises wearing out of the construction and material.

${ }^{24}$ Kompleksowy raport o stanie zachowania zabytków nieruchomych wpisanych do rejestru zabytków (Ksiegi Rejestru A I C, mps w zbiorach NID, s. 88.

25 To formulate the below mentioned conclusions and postulates the analyses results were used as still valid - the ones presented in the publication series of PKN ICOMOS, and especially the conclusions and suggestions formulated in the following articles: B. Szmygin, Historyczne ruiny średniowiecznych zamków $w$ Polsce - ocean stanu zasobu i prac konserwatorskich, /in:/ Zamki $w$ ruinie - zasady postepowania konserwatorskiego, ed. B. Szmygin and P. Molski, Warsaw - Lublin 2012, pp. 27-36; P. Molski, Pozakonserwatorskie uwarunkowania ochrony zamków $w$ ruinie, /In:/ Zamki w ruinie - zasady postępowania konserwatorskiego, pp. 49-55. The conclusions have been completed by the author of the current report on the basis of her own observations. 
At the same time there are no precise data concerning the amount of this type of monuments legally protected by registration as immovable property monuments. It is, then, necessary to catalogue the resource.

2. With respect to many objects it is necessary to explain the issue formally and correct the contents of the registration decision in order to precisely determine the object and the range of protection.

3. It is well justified to tend to reinforce the area protection of the ruins especially using the legal instruments within the competence of the local governments (the local area development plan and the culture park).

4. Not all the ruins of mediaeval castles are registered as immovable property monuments. A certain number is comprised by the 1 communal monument records. It would be fully justified to prepare a complete list of all the preserved objects of this category, and then estimating the quality of the castles (not included in the register), in order to choose the objects that should be comprised in the protected group by registration (with respect to the values they represent).

5. It is necessary to elaborate a complete, systemic, comparative estimation of the values of mediaeval castle ruins as a starting point for pointing out the strategy of protection of this resource.

6. It is justified to accept formally the rules formulated in the "Protection Charter of the Historical Ruins" as a standard of behavior accepted by the conservatory service.

7. Up to now the promotional and educational activities have mainly been carried out by the castle owners and their main objective is first of all the development of tourism. With regard to the value of the resource and the specific conditions of its protection as well as - most often - limited opportunities of exploitation it is advisable to carry out a nation-wide campaign promoting the rules and good examples of ruin exploitation ${ }^{26}$.

8. As far as the educational activity is concerned directed to the local community (and the wider group of the society) a suitable tool may be the promotion of good patterns - presenting the exploited goods efficiently used by the contemporaries in order to preserve their values according to the rules of permanent ruin protection.

\section{References}

1. Barełkowski R. Społeczna percepcja ruin zamkowych jako referencja dla potrzeb ochrony zabytków, /in:/ Trwała ruina II. Problemy utrzymania i adaptacji. Ochrona, konserwacja i adaptacja zabytkowych murów. ed. B. Szmygin, Lublin - Warszawa 2010, p. 7-16.

2. Barełkowski R. System wartości zabytkowej a ruina, /in:/ Zamki w ruinie - zasady postępowania konserwatorskiego, ed. B. Szmygin i P. Molski, Warszawa - Lublin 2012, pp.37-48.

3. Bogdanowski J. Trwała ruina zamku jako problem konserwatorsko-krajobrazowy. Ochrona Zabytków 1-2 (1977).

4. Bukal G. Zamki w Polsce. Kryteria oceny i formy ochrony, /in:/ Zamki, grody, ruiny. Waloryzacja i ochrona. ed. M. Lewicka, Warszawa - Białystok 2009, pp. 50-64.

5. Chlebowska D. Trwała ruina w Polsce koniecznym świadkiem historycznego krajobrazu. Wiadomości konserwatorskie 1 (2004).

${ }^{26}$ E.g. following the example of the campaign organized by the General Monument Conservator and the National Institute of National Heritage and regarding protection and shaping the urban culture areas as well as protection and preservation of the lay architecture and wooden construction - the campaign "The landscape of my city" and "Beautiful, wooden, Polish". 
6. $\quad$ Gruszecki A. Konserwacja ruin w Anglii. Ochrona zabytków 3-4 (1958).

7. Dettloff P. Wartości historycznych ruin $w$ Polsce wobec wspótczesnych zagrożeń $i$ szans ochrony, /in:/ Zamki, grody, ruiny. Waloryzacja i ochrona. ed. M. Lewicka, Warszawa - Białystok 2009, pp. 139-161.

8. Kurek J. Krzyżtopór - doktryna albo życie..., /w:/ Zamki w ruinie zasady postepowania konserwatorskiego. ed. B. Szmygin i P. Molski, Warszawa - Lublin 2012, pp. 160-168.

9. Lewicki J. Ochrona prawna a trwała ruina czy odbudowa. O sprzeczności polskiej teorii $i$ praktyki konserwatorskiej, /in:/ Zamki w ruinie zasady postępowania konserwatorskiego, pod ed. B. Szmygin i P. Molski, Warszawa - Lublin 2012, pp. 58-64.

10. Malawska I. Granice ruin zamkowych i granice ich otoczenie. Czy na podstawie decyzji o wpisie do rejestru zabytków nieruchomych można określić granice przedmiotu, który chronimy?, /in:/ Zamki w ruinie - zasady postepowania konserwatorskiego. ed. B. Szmygin i P. Molski, Warszawa - Lublin 2012, pp. 75-81.

11. Molski P. Pozakonserwatorskie uwarunkowania ochrony zamków w ruinie, /in:/ Zamki w ruinie zasady postepowania konserwatorskiego. ed. B. Szmygin i P. Molski, Warszawa - Lublin 2012, pp. 49-55.

12. Rymaszewski B. Granice adaptacji trwatych - zabytkowych ruin. Refleksje płynace z dziejów ochrony zabytków, /in:/ Trwała Ruina. Problemy utrzymania i adaptacji. ed. B. Szmygin, Lublin 2006, pp. 37-52.

13. Szmygin B. Doktryny i zasady konserwatorskie a wspótczesne możliwości ich realizacji. Ochrona Zabytków 2 (1997).

14. Szmygin B. Historyczne ruiny średniowiecznych zamków w Polsce - ocena stanu zasobu i prac konserwatorskich, /in:/ Zamki w ruinie zasady postępowania konserwatorskiego. ed. B. Szmygin i P. Molski, Warszawa - Lublin 2012, pp. 27-36.

15. Szmygin B. Ochrona ruin historycznych w Polsce - próba podsumowania wspótczesnych problemów, /in:/Zamki, grody, ruiny. Waloryzacja i ochrona. ed. M. Lewicka, Warszawa - Białystok 2009.

16. Szmygin B. Problem ruin zamku w świetle wspótczesnej teorii i praktyki konserwatorskiej, /w:/ Trwata Ruina. Problemy utrzymania i adaptacji. ed. B. Szmygin, Lublin 2006, pp. 25-36.

17. Tajchman J. Na czym polega metoda ochrony, konserwacji i zagospodarowania ruin zamkowych, /in:/ Zamki w ruinie zasady postępowania konserwatorskiego. ed. B. Szmygin i P. Molski, Warszawa - Lublin 2012, pp. 9-25. 